\title{
The First Record of Raillietina (Raillietina) celebensis (Janicki, 1902), (Cestoda) in Man from Australia, with a Critical Survey of Previous Cases
}

\author{
By Jean G. Baer and Dorothea F. Sandars* \\ University of Neuchâtel
}

Amongst material sent by Dr. M. J. Mackerras of the Queensland Institute of Medical Research, Brisbane, to one of us for identification were (a) a number of gravid proglottides collected from the faeces of a twenty-month old child from Brisbane, Australia, and (b) tapeworms from the duodenum of rats identified as Rattus assimilis Gould, from Mit. Glorious, South Queensland. They were all collected in 1955 .

Although only ripe proglottides were recovered from the child, these have been identified as Raillietina (Raillietina) celebensis (Janicki, 1902) on the basis of the position of the genital pore which is, in each proglottid, close to the anterior border. The cirrus pouch is 137 to $160 \mu$ long and 46 to $69 \mu$ in diameter. Each egg-capsule contains 1 to 4 eggs, 34 to $46 \mu$ in diameter. The proglottides have a markedly torulose appearance and are 1 to $2 \mathrm{~mm}$. long and 0.75 to $1.2 \mathrm{~mm}$. wide (Fig. B).

Among the cestodes from rats, were several complete worms identified as Raillietina (R.) celebensis (Janicki, 1902). These are 35 to $175 \mathrm{~mm}$. in length, with a maximum width of 1.4 to $1.75 \mathrm{~mm}$. The scolex, which is 274 to $411 \mu$ long and 480 to $803 \mu$ in diameter, bears four suckers each 114 to $183 \mu$ in diameter and with a number of very minute spines on the inside walls. The rostellum is 105 to $123 \mu$ in diameter and bears 160 hooks 18 to $23 \mu$ long arranged in two circlets. The mature proglottides have the typical anatomy

* On leave from the University of Queensland and the Queensland Institute of Medical Research, Brisbane ; holder of an Ohio State Grant 1955-56 awarded by the International Federation of University Women and a grant for 1955-56 made available through the trustees of the Science and Industry Endowment Fund of Australia. 
for this genus. The cirrus pouch is 114 to $151 \mu$ long and 50 to $73 \mu$ in diameter and the genital pore is always within the anterior quarter of the proglottid length. There are 28 to 30 testes ( 7 to 9 poral; 21 aporal) which have a diameter of 37 to $46 \mu$. In gravid proglottides there are 100 to 140 egg-capsules and in each capsule 1 to 4 eggs of $27 \mu$ diameter. The nearer to the posterior end of the worm the gravid proglottides are, the more torulose they are in shape (Fig. A).

These tapeworms fall within the incomplete description given by Janicki (1902), for Davainea celebensis and the redescription given by Meggitt \& Subramanian (1927). There have been described no less than six further species of Raillietina (Raillietina) which have been, or may be, regarded as synonyms of $R$. (R.) celebensis.

Joyeux \& Baer (1929) recognised $R$. (R.) formosana (Akashi, 1916) as a synonym. An examination of Table $I$ will show that the variety $R$. (R.) celebensis paucicapsulata Meggitt \& Subramanian, 1927, $R$. (R.) funebris Meggitt \& Subramanian, 1927, $R$. (R.) garrisoni Tubangui, 1931, $R$. (R.) sinensis Hsu, 1935, all have the same range in numbers and size of rostellar hooks and testicular follicles and agree in the anterior position of the genital pore. They also agree in other features, such as in the presence of spines both on the rostellum and the suckers and in the range for number of eggs in each capsule. $R$. (R.) murium Joyeux \& Baer, 1936, when considered from the description given, is strikingly different from the other forms in the number of rostellar hooks and in the number of testicular follicles. However, re-examination of the material described by these authors reveals that the number of hooks and testes do fit within the range for $R$. (R.) celebensis. All these species are from the same geographic region. They are all now, regarded as synonyms of Raillietina (R.) celebensis (Janicki, 1902).

Material from Rattus norvegicus from Hanoi has also been examined and its features shown in Table $I$. It is identified as $R$. (R.) celebensis.

The ripe proglottides from the child bear a striking resemblance to the gravid proglottides of $R$. $(R$.) celebensis from the Queensland rat. They may be regarded as being from the same locality, since IIt. Glorious is within $\mathbf{3 0}$ miles from the centre of Brisbane. There can be little doubt that they are infections with the same species of cestode and that the child has acquired, secondarily, this infection from normal rat hosts. 
(3)

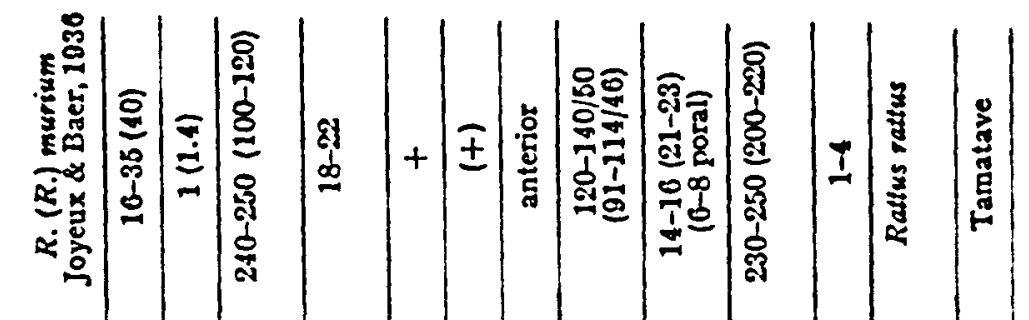

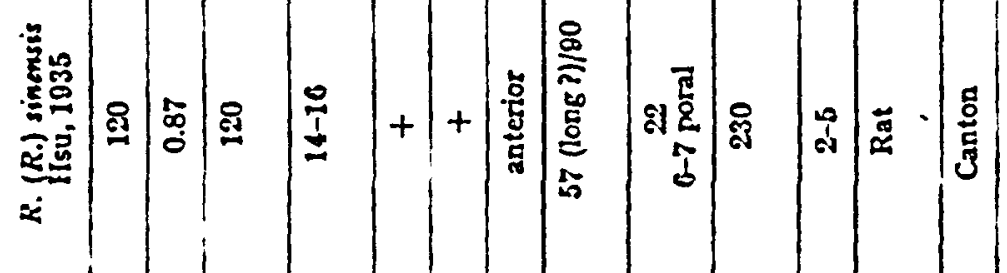

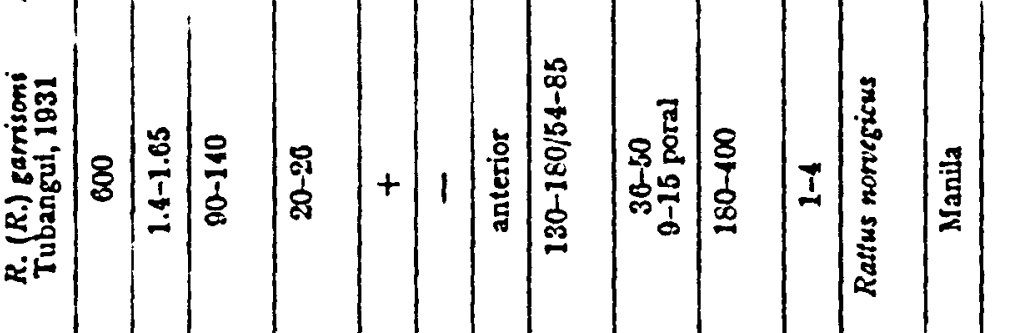

$$
\begin{aligned}
& \text { 害苛重 } \\
& \text { 运哥 }
\end{aligned}
$$

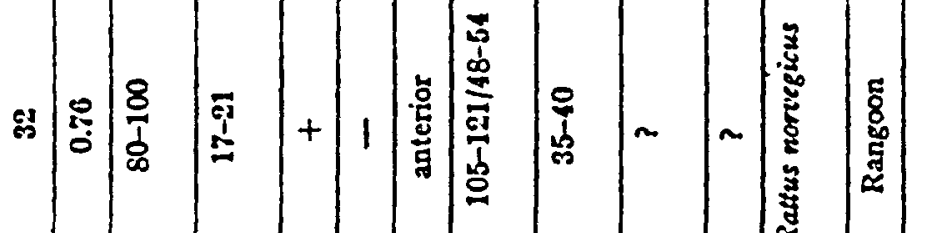

$$
\begin{aligned}
& \text { 눙 }
\end{aligned}
$$

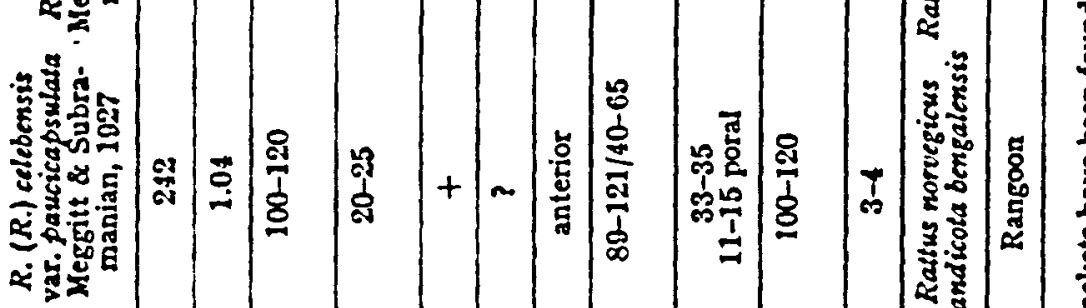

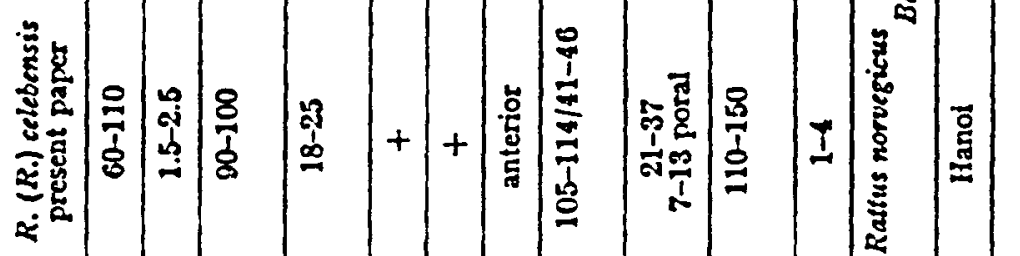

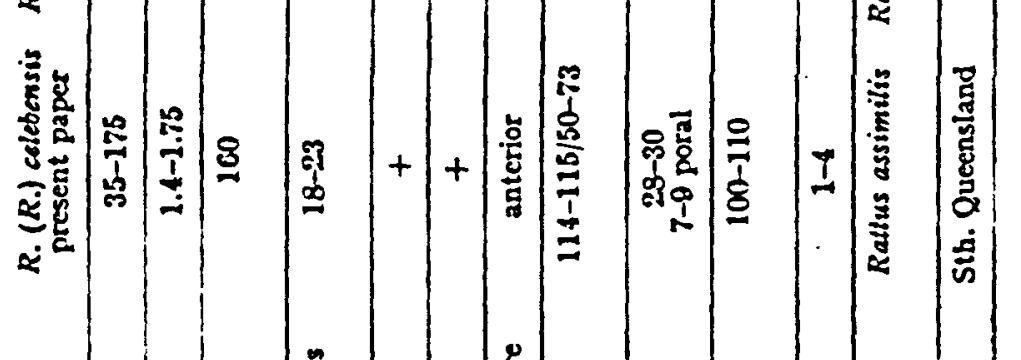

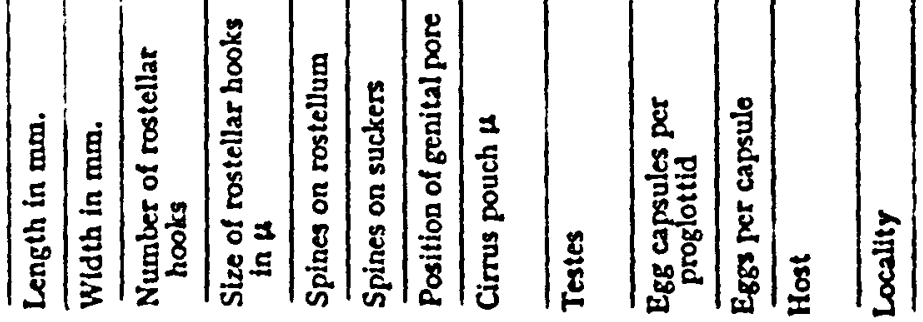


This is the first time that $R$. (R.) celebensis (Janicki) has been reported from Australia both from a child, and an autochtonous rat.* But since this tapeworm was first reported from Lenomys meyeri (Jentinck) from the Celebes, it very likely occurs throughout Australasia. $R$. (R.) celebensis has been found in rodents in the Philippines, Southern China, Formosa, Burma and Madagascar. It has been reported from man, in Siam (Leuckart, 1891), Formosa (Akashi, 1916), Philippines (Garrison, 1911, Africa \& Garcia, 1934) and Queensland (present paper). It will, doubtless, be found elsewhere within this region, if searched for systematically.

The species of Raillietina (sen Davainea) reported from man were first reviewed by Joyeux \& Baer (1929) after an examination of the original material deposited in the Blanchard collection in Paris. They came to the following conclusions :

1. Taenia demerariensis Daniels, 1895, from British Guiana, is distinct from $T$. madagascariensis Davaine, 1869. An opinion that was later vindicated by the same authors $(1940 ; 1949)$ (vide infra).

2. Under the name $T$. madagascariensis Davaine, 1869 , there appear to have been described two distinct species: one from the Comores and Mauritius, and the other from Nossi Bé.

3. T. madagascariensis Garrison, 1911, from man in Manila, is a synonym of $R$. (R.) celebensis (Janicki) from rodents.

4. T. madagascariensis Leuckart, 1891, from a child in Bangkok, appears to be distinct from the above species. Its possible relationship to $T$. madagascariensis from the Comores, is discussed.

5. Several tapeworms belonging to the genus Raillietina, also occur in rodents, they may have been passed, secondarily. to man.

Subsequently, Tubangui (1931), reported a tapeworm from Philippine rats which is identical to the species described by Garrison (loc. cit.). Joyeux \& Baer (1936) recorded a species of Raillietina found in Rattus rattus at Tamatave (Madagascar), which they were unable to identify with any of the species described from either the Comores or Mauritius.

- Ellermann (Proc. Zool. Soc. Lond. 1947, p. 262) is of the opinion that Rattus assimilis Gould is probably a race of $R$. rattus. 
Re-examination of the fragments of the worms described by Joyeux \& Baer (1929), from the collections of Blanchard and Davaine, has shown that in these the genital pore is always in the middle of the lateral border of the segment. This is in contradistinction to the position of the sexual aperture in $R$. (R.) celebensis which is invariably either in the anterior third of the lateral border in each
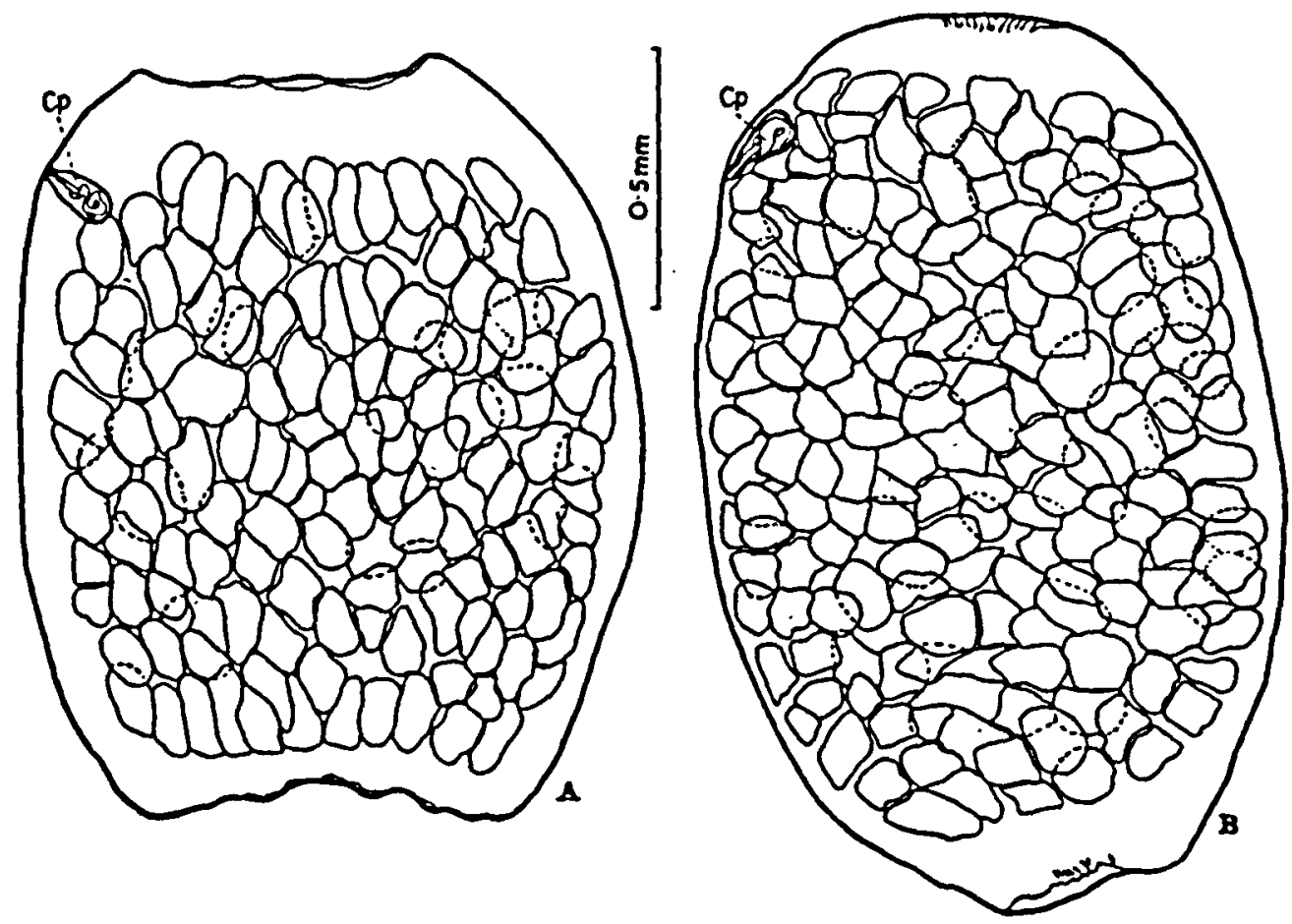

Gravid proglottides of $R$. (R.) celebensis : A.-from a Queensland Rat; B.-from a Queensland child. Cp.-cirrus pouch.

proglottid, or, as is more frequent, in the anterior quarter. Moreover, the fragments of the various strobilas reveal an internal anatomy not unique for the genus Raillietina but also identical with that of the genus Inermicapsifer. Inermicapsifer can be distinguished only in that all the species possess an unarmed scolex. They are found in rodents, hyraxes and man, in Africa*.

- I. arvicanthidis (Kofend), a frequent parasite of African rodents, has been reported at least three times from children in East Africa, and appears to occur quite commonly in man in Cuba (Baer, Kouri and Sotolongo, 1949 ; Baer, 1955). The first case observed by Davaine (1869) at Mayotte, was from a Creole child who had come from the West Indies ! 
Since Joyeux \& Baer (1929) consider that the scolex, described by Blanchard as belonging to $T$. madagascariensis, is that of $T$. saginata, therefore no entire worm complete with scolex, has ever been described from the Comores or from Mauritius. In view of the above observations, we propose to consider the tapeworm from man, described in all textbooks under the name Raillietina (R.) madagascariensis as a species sub judice since it is at present, quite impossible to establish its true identity. In the hope of rediscovery of this tapeworm it would be necessary to obtain further material from either man or rodents, or both, from the Comores or Mauritius.

In the New World, Joyeux \& Baer (1951) have established the existence of two species of Raillietina $(R$.$) viz. R$. (R.) demerariensis (Daniels, 1895) from man and a Howler monkey in the Guianas and Ecuador, and $R$. (R.) alouattae Baylis, 1947 from Howler monkeys in Surinam. At the time, the above authors overlooked a paper by Perez-Vigueras (1943) in which is described $R$. (R.) halli PerezVigueras, 1943 from a wild rodent in Cuba.*

Cameron \& Reesal (1951) have described tapeworms from wild rodents from Trinidad, which they consider to be a variety of $R$. (R.) demerariensis which is named var. trinitatae. In a later paper, Stunkard (1953) reports this variety from a Venezuelean rodent and considers it to be identical with $R$. $(R$.) demerariensis, as redescribed by Joyeux \& Baer (1951).

We have been able to examine numerous specimens of $R$. $(R$. halli collected from the type host, Capromys pilorides Say in Cuba and have found this species to be identical with $R$. $(R$.$) demerariensis$ (Daniels). On the other hand, the variety described by Cameron \& Reesal is certainly not a synonym of $R$. (R.) demerariensis, as was suggested by Stunkard. Both the size of the rostellar hooks and the number of testes provide sufficient distinctive characters for separating them into two species. We therefore propose to raise the variety to specific rank and to name it $R$. (R.) trinitatae (Cameron \& Reesal, 1951) nov.comb.

- It is interesting to find that in Cuba, wild rodents harbour tapeworms of the genus Raillietina, whereas man harbours a species of Inermicapsifer (vide supra) which has not yet been observed in any wild Cuban rodent. 
The three species of Raillietina from mammals in the Neotropical region may be differentiated upon the following basis:

1. More than 80 testes per segment .........R. alouattae Baylis, 1947

Less than 80 testes per segment

2. Rostellar hooks $10-18 \mu ; 26-46$ testes

R. trinitatae (Cameron \&. Reesal, 1951)

Rostellar hooks $18-20 \mu ; 50-70$ testes

$R$, demerariensis (Daniels, 1895)

In the following the synonyms of these three species, and also those for $R$. (R.) celebensis, are listed, the host list and distribution given and the diagnosis of each species. The latter has been based, wherever possible, on examination of fresh material.

RaILLIETINA (R.) CELEBeNSIS (Janicki, 1902), Fuhrmann, 1920

Syn. Davainea madagascariensis Leuckart, 1891 nec Davaine, 1869; Davainea celebensis Janicki, 1902; Davainea madagascariensis Garrison, 1911 nec Davaine, 1869; Davainea formosana Akashi, 1910; Raillietina (R.) celebensis (Janicki), Fuhrmann, 1920 ; Raillietina (R.) celebensis var. pancicapsulata Meggitt \& Subramanian, 1927; Raillietina (R.) formosana (Akashi), Joyeux \& Baer, 1929 ; Raillietina (R.) garrisoni Tubangui, 1931 ; Raillietina (R.) sinensis Hsu, 1935 ; Raillietina (R.) murium Joyeux \& Baer, 1936 : Meggittia celebensis (Janicki), Lopez-Neyra, 1943.

Hosts : Man, Rattus rattus L., $R$. norvegicus Berkenhout, $R$. assimilis Gould, Bandicota bengalensis (Gray \& Hardw.), Lenomys meyeri (Jentink).

Distribution: Canton, Formosa, Hanoi, Rangoon, Tamatave, Manila, South Queensland.

Diagnosis : The length is $16-600 \mathrm{~mm}$. with a maximum width of $2.5 \mathrm{~mm}$. The scolex is $0.30-0.80 \mathrm{~mm}$. in diameter. The rostellum which has a covering of small spines, bears 80-160 hooks, 14-26 $\mu$ long. The four suckers are armed with minute spines and are 91$183 \mu$ in diameter. The genital pore is within the anterior third of the lateral border in each proglottid. The cirrus pouch is $89-180 \mu$ long and $40-85 \mu$ in diameter. There are 21-50 testes, 37-50 $\mu$ in diameter, with the greater number on the aporal side of each 
proglottid. The egg capsules are numerous (100-230) ; each capsule contains 1-4 eggs.

RAILLIETINA (R.) DEMERARIENSIS (Daniels, 1895), Joyeux \& Baer, 1929.

Syn. Taenia demerariensis Daniels, 1895; Davainea madagascariensis auctorum nec Davaine, 1869 ; Raillietina (R.) demerariensis (Daniels), Joyeux \& Baer, 1929; Raillietina (R.) quitensis Leon, 1035 ; Raillietina (R.) brumpti Dollfus, 1939 ; Raillietina (R.) equatoriensis Dollfus, 1939 ; Raillietina $(R$.$) leoni Dollfus, 1939$; Raillietina $(R$.$) luisaleoni Dollfus, 1939$; Raillietina $(R$.$) halli$ Perez-Vigueras, 1943.

Hosts: Man, Alouatta seneculus (L.), Capromys pilorides Say.

Distribution : Ecuador, British Guiana, Cuba.

Diagnosis : The length is $90-120 \mathrm{~mm}$. with a maximum width of $1.3-1.8 \mathrm{~mm}$. The scolex has a diameter of $450 \mu$. The rostellum is armed with 200-300 rostellar hooks, each $18-20 \mu$ long. The four suckers are armed with small spines. There are 50-70 testes in each segment. The cirrus pouch is $180-220 \mu$ long and $80-90 \mu$ in diameter. The egg capsules in the gravid segments are numerous (180). Each capsule contains 8-10 eggs.

RailletetiNa (R.) alouattae Baylis, 1947

Syn. Raillietina (R.) multitesticulata Perkins, 1950.

Hosts : Alouatta seneculus (L.), A. macconnelli Elliot.

Distribution: British and Dutch Guianas.

Diagnosis : The length is $130-340 \mathrm{~mm}$. with a maximum width of 3.2-7 mm. The diameter of the scolex is $450-700 \mu$. The rostellum bears 175-245 hooks, each 15-18 $\mu$ long. The four suckers bear small spines. There are 110-140 testes per segment. The cirrus pouch is $220-308 \mu$ long and $100 \mu$ in diameter. The egg capsules are relatively few in the gravid segments $(70-85)$ and each capsule contains 6-11 eggs. 
RaIllietiNa (R.) trinitataE (Cameron \& Reesal, 1951) nov.comb.

Syn. Raillietina $(R$.$) demerariensis var. trinitatae Cameron \&$ Reesal, 1951; Raillietina (R.) demerariensis Stunkard, 1953-nec. Daniels, 1895.

Hosts : Caniculus paca (L.), Dasyprocta aguti (L.), Proechimys cayennensis (Desm.).

Distribution : Trinidad, Venezuela.

Diagnosis : The length is $60-100 \mathrm{~mm}$. and the maximum width, 1.3-2.7 mm. The diameter of the scolex is $270-370 \mu$. The rostellum has 170-175 hooks, $10-11 \mu$ long. The four suckers are armed with minute spines. There are 26-46 testes in each segment. The cirrus pouch is $120-300 \mu$ long and $50-70 \mu$ in diameter. The egg capsules are numerous in the gravid proglottides (80-240). Each egg capsule contains 2-12 eggs.

\section{SUMIMARY}

Gravid proglottides of Raillietina $(R$.$) celebensis (Janicki) are$ reported from a child in Brisbane, Queensland. Complete tapeworms of the same species are reported from Rattus assimilis Gould, from Mt. Glorious, South Queensland. A critical survey is made of all the cases previously recorded from man. Raillietina $(R$.) madagascariensis is for the present, regarded as a species sub judice. Raillietina (R.) demerariensis var. trintitatae Cameron \& Reesal, 1951 has been raised to specific rank and named $R$. (R.) trinitatae (Cameron \& Reesal, 1951) nov.comb. The synonyms of $R$. (R.) celebensis; $R$. $(R$.$) demarariensis; R .(R$.$) alouattae and$ $R$. (R.) trinitatae, are discussed.

\section{ACKNOWLEDGMENT}

We are indebted to Dr. M. J. Mackerras for forwarding the Queensland material examined and identified.

\section{REFERENCES}

AFrICA, C. MI. and GARCIA, E. Y., 1934.--"A Rat Tapeworm (Raillietina garrisoni Tubangui, 1931) transmissible to Man. With notes on Davainea madagascariensis Garrison, 1911." Philipp. J. Pub. Health, 1, 44-51.

BAER, JeAN G., 1955.- “Un nouveau cas de parasitisme d'un enfant en Afrique orientale par le cestode Inermicapsifer arvicanthidis (Kofend, 1917)." Acta brop., Basel, 12, 174-176. (WV.L. 12la) 
BAyzis, H. A., 1947.- "Some Roundworms and Flatworms from the West Indies and Surinam, II. Cestodes." J. Linn. Soc. (Zool.), 41, 406-414. (W.L. 11296)

Cameron, T. W. and Reesil, M. R., 1951.- "Studies on the endoparasitic fauna of Trinidad Mammals, VII. Parasites of Hystrichomorph Rodents." Canad. J. Zool., 29, 276-289, 24 figs.

-Joyeux, Ch. and BAER, J. G., 1929._- "Les cestodes rares de l'homme." Bull. Soc. Pat. exot., 22, 114-136. (W.L. 5310)

1936. - "Sur quelques Cestodes de Madagascar. ibid, 32, 39-43, 2 figs.

1940.- "Anatomia y posicion sistematica de Raillietina (Raillietina) quitensis Leon, 1935. Cestode parasito del Hombre." Rev. Med. trop., Havana, 6, 70-88, 3 figs. (W.L. 18902a)

1949.-"L'hôte normal de Raillietina (R.) demerariensis (Daniels, 1895) en Guyane hollandaise." Acta trop., Basel, 6, 141-144. (W.L. 121a)

LOPEz-NEYRA, C. R., 1943.- "Las Raillietinas parasitas humas." Rev. ibér. Parasit., 3, 141-168; 257-258, 3 pls. (W.L. 18858c)

Perez-Vigueras, I., 1943.-. "Un genero y cinco especies nuevas de helmintos cubanos." Univ. Habana, 41 pp. 19 figs.

Perxins, K. W., 1950.-“A new Cestode, Raillietina (R.) multitesticulata n.sp. from the Red Howler Monkey." $J$. Parasit., 36, 293-296, 6 figs. (V.L. 11428)

Stunkard, H. W., 1953.-Raillietina demerariensis (Cestoda), from Proechimys cayennensis trinitatus of Venezuela. ibid., 39, 1-8, 4 figs.

Tubangur, M., 1931.- "Worm parasites of the Brown Rat (Mus norvegicus) in the Philippine islands, with special reference to those forms that may be transmitted to human beings." Philipp. J. Sci., 46, 537-591, 10 figs. (W.L. 16189)

- This paper contains all the literature cited prior to 1929. 